\title{
Perbandingan Skoring Kualitas Hidup Pasien Kanker dengan Menggunakan EORTC QLQ-C30 dan FACT-G: Literatur Review
}

\section{Comparison of Quality of Life Scoring of Cancer Patients Using EORTC QLQ-C30 and FACT-G: Literature Review}

\author{
Cynthia Tri Wardhani ${ }^{1}$, Dewi Gayatri2 ${ }^{\otimes}$, Tuti Nuraini $^{3}$ \\ 1,2,3Fakultas Ilmu Keperawatan Universitas Indonesia
}

\section{ABSTRAK}

Latar Belakang: Kanker merupakan penyakit yang dapat memberikan efek negatif pada fungsi tubuh sehingga memengaruhi kualitas hidup. Pengukuran kualitas hidup dapat menggunakan berbagai instrumen.

Tujuan: Menelaah hasil penelitian mengenai perbandingan skoring kualitas hidup pasien kanker dengan menggunakan EORTC QLQ-C30 dan FACT-G.

Metode: Literature review dengan PRISMA checklist sebagai protokol. Analisis bias menggunakan Joanna Briggs Institute (JBI) Critical Appraisal. Pencarian artikel dilakukan Mei-Juli 2020, dengan menggunakan database ClinicalKey, EBSCOhost, Google scholar, ProQuest, dan PubMed. Dari 1.194 artikel yang ditemukan, sebanyak 17 artikel sesuai kriteria inklusi.

Hasil: Skor kualitas hidup pada instrumen QoL FACT-G lebih tinggi dibandingkan dengan EORTC QLQ-C30. Selain itu, pada dimensi kualitas hidup dan fisik menunjukkan hubungan yang kuat $(\mathrm{r}=0,54$ $-0,76)$, tetapi lemah pada dimensi sosial $(\mathrm{r}=0,00-0,130)$.

Kesimpulan: Penelitian ini merekomendasikan FACT-G sebagai instrumen yang mengukur kualitas hidup secara holistik serta berfokus pada psikososial.

Kata Kunci: EORTC QLQ-C30; FACT-G; Kualitas Hidup

\section{ABSTRACT}

Background: Cancer is a disease that can hurt bodily functions that affect the quality of life (QoL). Quality of life can be measured by a variety of instruments.

Objective: To examine the results of research on the comparison of quality-of-life scoring in cancer patients using EORTC QLQ-C30 andFACT-G.

Methods: A literature review with the PRISMA checklist as a protocol. Biased analysis usedthe Joanna Briggs Institute (JBI) Critical Appraisal. Search for articles was conducted from May to July 2020, using the ClinicalKey, EBSCOhost, Google Scholar, ProQuest, and PubMed databases. Of1,194 articles, 17 articles were according to the inclusion criteria.

Results: QoL FACT-G score was higher than the EORTC QLQ-C30. Besides, the quality of life and physical dimensions showed a strong relationship $(r=0.54-0.76)$, but wasweak in the social dimension $(r=0.00-$ 0.130).

Conclusion: This study recommends FACT-G as an instrument that measures QoL holistically and focuses on psychosocial.

Keywords: EORTC QLQ-C30, FACT-G, Quality of Life 
PENDAHULUAN

Kanker adalah kelompok penyakit yang ditandai dengan adanya pertumbuhan dan penyebaran sel abnormal dan tidak terkendali (Daniels \& Nicoll, 2012). Terdapat faktor yang berkontribusi dalam perkembangan kanker, yaitu keturunan, lingkungan, dan gaya hidup. Gaya hidup yang tidak sehat seperti merokok merupakan sebagai faktor risiko utama yang menyebabkan lebih dari $20 \%$ kematian akibat kanker di dunia (Kementerian Kesehatan RI, 2015).

Terapi kanker memberikan efek ketidaknyamanan bagi pasien, seperti rasa nyeri, kelelahan, dan gangguan tidur. Kondisi tersebut dapat memengaruhi kualitas hidup pasien kanker. Menurut WHO, kualitas hidup merupakan persepsi individu terhadap dirinya sendiri dalam kehidupan berdasarkan budaya dan norma-norma yang berlaku dan dikaitkan dengan standar, tujuan, dan harapan (Nilsson, 2012).

Menurut Tothova et al. (2014), penilaian kualitas hidup terdiri dari empat domain, yaitu kesejahteraan fisik, sosial, psikologis, dan spiritual. Kualitas hidup pada pasien kanker dapat dinilai dengan menggunakan instrumen European Organization for Research and Treatment of Cancer Quality of Life Questionnaire-C-30 (EORTC QLQ-C30) dan Functional Assessment of Cancer Therapy-General (FACT-G).

EORTC QLQ-C30 merupakan instrumen yang berisi 30 pertanyaan dan terdiri dari lima skala fungsional, tiga skala gejala, enam skala tunggal, dan satu kualitas hidup secara global (Noviyani et al., 2016). FACT-G merupakan instrumen yang berisi 27 pertanyaan dengan empat domain, yaitu kesejahteraan fisik, sosial atau keluarga, emosional dan fungsional (Sato et al.,2014).

Artikel mengenai perbandingan EORTC QLQ-C30 dan FACT-G dalam mengukur kualitas hidup pasien kanker masih sangat terbatas untuk ditemukan.
Di Jepang, penelitian mengenai perbandingan EORTC QLQ-C30 dengan FACT-G dilakukan oleh Sato, et al. (2014). Pada penelitian tersebut didapatkan bahwa pasien kanker secara signifikan lebih menyukai FACT-G dibandingkan EORTC QLQ-C30 dalam hal kepentingan, kebutuhan, dan kesesuaian.

Tujuan dari literature review ini adalah untuk mengetahui perbandingan skoring kualitas hidup pasien kanker menggunakan kuesioner EORTC QLQ -C30 dengan FACT-G.

\section{METODE}

Metode yang digunakan dalam penelitian ini ialah telaah literatur (literature review) dengan menggunakan PRISMA Checklist sebagai protokol penulisan dan Joanna Briggs Institute (JBI) Critical Appraisal untuk analisis bias. Pencarian literatur dilakukan pada bulan Mei-Juli 2020 melalui Clinical Key, EBSCOhost, Google scholar, ProQuest, dan PubMed.

Kata kunci yang digunakan menyesuaikan MeSH, yaitu "Comparison", "Perbandingan", "Validation", "Validitas", “EORTC QLQ-C30”, “FACT-G”, “Quality of Life", "Kualitas Hidup", "Cancer", "Kanker", "Neoplasms", "Neoplasma" yang digabungkan dengan boolean operator (AND, OR and NOT). Kriteria inklusi, di antaranya: (1) semua penelitian dilakukan pada pasien kanker, (2) hasil: skor kualitas hidup yang diukur dengan EORTC QLQC30 dan FACT-G, (3) desain studi: cross sectional, cohort, systematic review, casecontrol, (4) bahasa: Inggris dan Indonesia, (4) artikel full-text.

Pemilihan artikel dilakukan dengan tahapan, yaitu: (1)melakukan pencarian artikel pada mesin pencarian, (2) melakukan penyeleksian artikel terhadap ketersediaan full-text dan terduplikat, (3) melakukan penyeleksian artikel sesuai dengan kriteria inklusi, (4) melakukan analisis bias (5) hasil penelitian di ekstraksi dalam bentuk tabel dengan 
format nomor, penulis, tahun publikasi, judul artikel, metode, dan ringkasan hasil penelitian. Dalam analisis bias, tujuh belas artikel menunjukkan skor 50\% atau lebih.

\section{HASIL DAN PEMBAHASAN}

Berdasarkan hasil pencarian didapatkan artikel sebanyak 1.194, kemudian diperiksa duplikasi dan ditemukan sebanyak 392 artikel sehingga tersisa 802 artikel. Peneliti kemudian menyeleksi artikel yang tidak full-text, ditemukan sebanyak 298 sehingga jumlah artikel menjadi 504.

Setelah itu, peneliti melakukan screening terhadap abstrak pada setiap literatur, sebanyak 487 artikel diekslusikan. Setelah diekslusikan, total artikel yang nantinya akan dilakukan review yaitu 17 artikel. Adapun alur seleksi ditunjukkan pada Gambar 1.

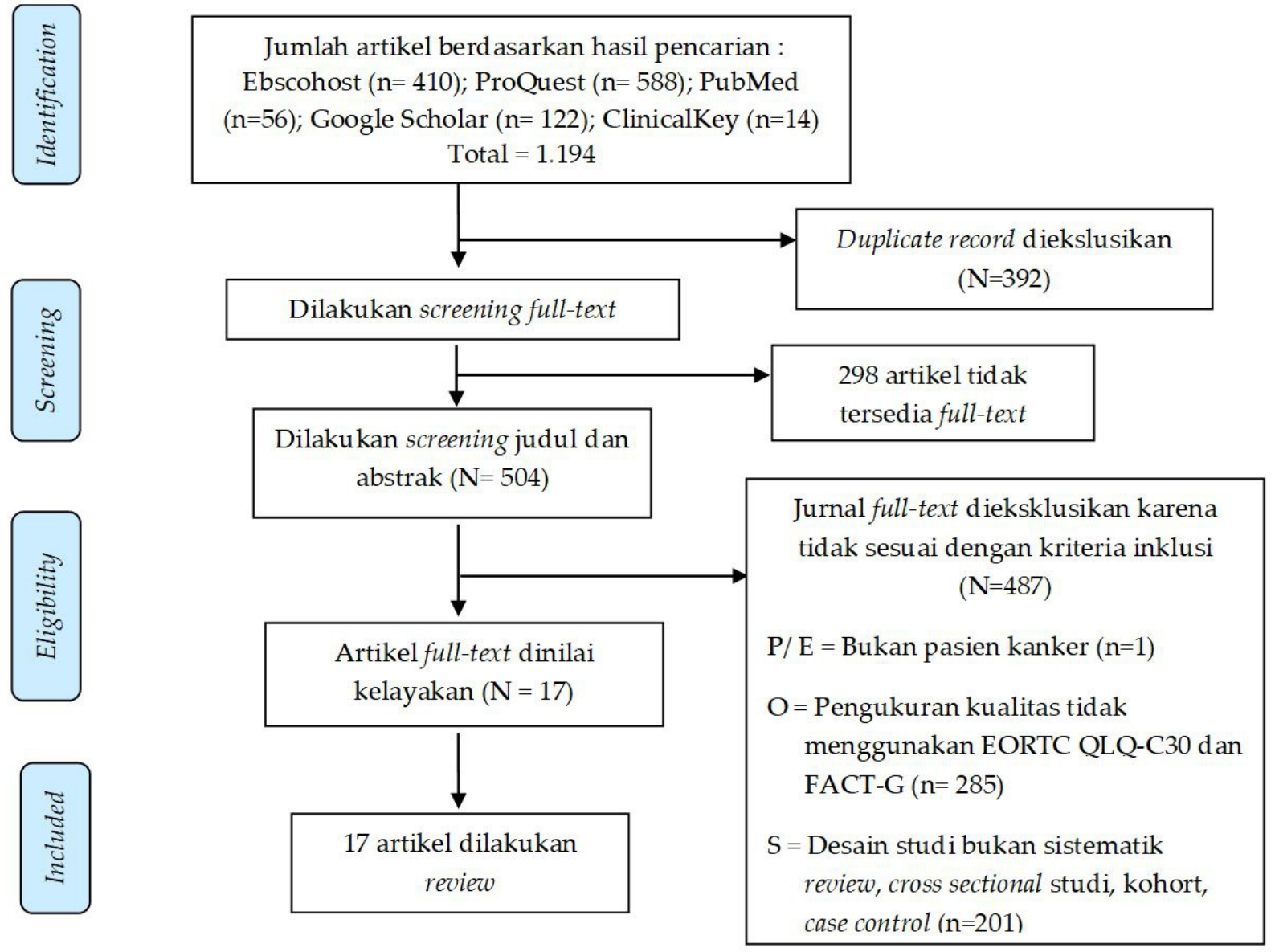

Gambar 1. Diagram Flow PRISMA 2009

Tabel 1. Perbandingan QOL EORTC QLQ-C30 dengan FACT-G

\begin{tabular}{|c|c|c|c|}
\hline No & & EORT QLQ-C30 & FACT-G \\
\hline 1 & $\begin{array}{l}\text { (Georgakopoulos et } \\
\text { al., 2013) }\end{array}$ & $\begin{array}{l}\text { - Qlobal health status/ QoL = } 66(18,7) \\
\text { - Fungsi fisik = 76,2 }(18,3) \\
\text { - Fungsi peran = 69,3 }(29,1) \\
\text { - Fungsi emosional = 75,6 }(18,3) \\
\text { - Fungsi sosial = 72,2 }(26,6)\end{array}$ & $\begin{array}{l}\text { - Total skor FACT-G = 80,1 }(15,7) \\
\text { - Kesejahteraan fisik = 20,9 }(5,3) \\
\text { - Kesejahteraan fungsional = } 18,5(5,6) \\
\text { - Kesejahteraan emosional =18,1 }(4,1) \\
\text { - Kesejahteraan sosial = 22,4 }(4,3)\end{array}$ \\
\hline 2 & (Irvani et al., 2018) & $\begin{array}{l}\text { - Qlobal health status } / \mathrm{QoL}=53,66 \pm 22,35 \\
\text { - Fungsi fisik }=75,25 \pm 17,35 \\
\text { - Fungsi peran }=76,26 \pm 23,30 \\
\text { - Fungsi emosional }=62,69 \pm 27,08 \\
\text { - Fungsi sosial }=61,49 \pm 28,62\end{array}$ & $\begin{array}{l}\text { - Kesejahteraan fisik }=17,21 \pm 5,42 \\
\text { - Kesejahteraan fungsional =14,73 } \pm 3,98 \\
\text { - Kesejahteraan emosional }=13,03 \pm 4,79 \\
\text { - Kesejahteraan sosial }=17,16 \pm 5,15\end{array}$ \\
\hline 3 & (Sato et al., 2014) & $\begin{array}{l}\text { - Qlobal health status/ QoL }=66 \pm 23 \\
\text { - Fungsi fisik }=90 \pm 15\end{array}$ & $\begin{array}{l}\text { - Total skor FACT-G }=56 \pm 6 \\
\text { - Kesejahteraan fisik }=78 \pm 19\end{array}$ \\
\hline
\end{tabular}


Tabel 1. Perbandingan QOL EORTC QLQ-C30 dengan FACT-G (lanjutan...)

\begin{tabular}{lll}
\hline No & \multicolumn{1}{c}{ EORT QLQ-C30 } & \multicolumn{1}{c}{ FACT-G } \\
\hline & $\bullet$ Fungsi peran $=86 \pm 22$ & $\bullet$ Kesejahteraan fungsional $=61 \pm 18$ \\
& $\bullet$ Fungsi emosional $=80 \pm 22$ & $\bullet$ Kesejahteraan emosional $=64 \pm 16$ \\
& $\bullet$ Fungsi sosial = $82 \pm 25$ & \\
& & Kesejahteraan sosial $=48 \pm 15$ \\
$4 \quad($ Teckle et al., 2011) & $\bullet$ Qlobal health status/QoL $=68,90(20,36)$ & $\bullet$ Total skor FACT-G $=81,61(14,14)$ \\
\hline
\end{tabular}

Tabel 2. Korelasi Antara EORTC QLQ-C30 dengan FACT-G

\begin{tabular}{|c|c|c|c|c|c|c|c|c|}
\hline \multirow[b]{2}{*}{ No } & \multirow[b]{2}{*}{ Negara } & \multirow[b]{2}{*}{ Sampel Penelitian } & \multicolumn{5}{|c|}{ Korelasi Skala EORTC QLQ-C30 dengan FACT-G } & \multirow{2}{*}{$\begin{array}{c}\text { Koefisien } \\
\text { Korelasi }\end{array}$} \\
\hline & & & Fisik & Emosional & Sosial & $\begin{array}{l}\text { Fungsional } \\
\text { atau peran }\end{array}$ & $\begin{array}{l}\text { QoL/ Total } \\
\text { FACT-G }\end{array}$ & \\
\hline 1 & Jepang & $\begin{array}{l}\text { Pasien kanker dewasa yang } \\
\text { sedang rawat jalan }(\mathrm{N}=400)\end{array}$ & $0,65^{*}$ & $0,60^{*}$ & 0,001 & $0,41^{*}$ & $0,54^{*}$ & $\begin{array}{l}\text { Pearson } \\
\text { correlation }\end{array}$ \\
\hline 2 & $\begin{array}{l}\text { British } \\
\text { Columbi, } \\
\text { Kanada }\end{array}$ & $\begin{array}{l}\text { Pasien kanker payudara, } \\
\text { kolorektal dan paru-paru } \\
(\mathrm{N}=184)\end{array}$ & $0,55^{*}$ & $0,761^{*}$ & 0,130 & $0,607^{*}$ & $0,629^{*}$ & $\begin{array}{l}\text { Pearson } \\
\text { correlation }\end{array}$ \\
\hline 3 & Yunani & $\begin{array}{l}\text { Pasien Hodgkin lymphoma } \\
\text { dan diffuse large B-cell } \\
\text { lymphoma }(\mathrm{N}=80)\end{array}$ & $0,58^{* *}$ & $0,39^{* *}$ & $0,46^{* *}$ & $0,51^{* *}$ & $0,65^{* *}$ & $\begin{array}{l}\text { Spearman } \\
\text { correlations }\end{array}$ \\
\hline 4 & Kanada & $\begin{array}{l}\text { Pasien kanker Esophageal } \\
(\mathrm{N}=54)\end{array}$ & 0,53 & 0,67 & 0,47 & 0,58 & 0,58 & $\begin{array}{l}\text { Spearman } \\
\text { correlations }\end{array}$ \\
\hline 5 & Inggris & $\begin{array}{l}\text { Pasien kanker esophageal } \\
(\mathrm{N}=57)\end{array}$ & $0,67^{* *}$ & $0,64^{* *}$ & 0,01 & $0,57^{* *}$ & $0,76^{* *}$ & $\begin{array}{l}\text { Spearman } \\
\text { correlations }\end{array}$ \\
\hline
\end{tabular}

Perbandingan Skor Kualitas Hidup dengan EORTC QLQ-C30 dan FACT-G

Beberapa studi menunjukkan bahwa skor QoL FACT-G lebih tinggi dibandingkan EORTC QLQ-C30 (Georgakopoulos et al., 2013; Teckle et al., 2011). Namun, pada penelitian Sato et al. (2014) menunjukkan skor QoL EORTC QLQ-C30 lebih tinggi dibandingkan FACT-G.

Perbedaan tersebut terjadi karena perbedaan jumlah sampel dan tempat penelitian. Selain itu, skor kualitas hidup EORTC QLQ-C30 didapatkan dari ratarata respons dua item, dimana pasien langsung mengukur sendiri kualitas hidupnya dengan skala Likert tujuh poin tanpa menggabungkan skala lainnya, sedangkan pada FACT-G didapatkan dari penjumlahan 27 item dengan skala Likert lima poin yang mencerminkan kualitas hidup.

Berdasarkan telaah literatur, penelitian ini merekomendasikan FACT-G sebagai instrumen yang mengukur kualitas hidup pasien kanker karena ditinjau dari berbagai aspek secara holistik dibandingkan dengan EORTC QLQ-C30.

Selain itu, antara dimensi sosial/ keluarga EORTC QLQ-C30 dengan FACT$G$ memiliki korelasi yang lemah dibandingkan dengan dimensi lainnya (Blazeby et al., 2005; Sato et al., 2014; Silpakit et al., 2006; Teckle etal., 2011). Pada dimensi fungsional menunjukkan korelasi yang sedang (Sato etal., 2014). Korelasi yang lemah pada skala sosial disebabkan adanya perbedaan konten, di mana EORTC QLQ-C30 menilai dampak pengobatan medis dan keluhan fisik terhadap kegiatan sosial, sedangkan FACT-G cenderung pada dukungan dan hubungan keluarga, teman, dan pasangan atau orang terdekat lainnya.

Luckett et al. (2011) menyatakan bahwa terdapat perbedaan yang penting antara EORTC QLQ-C30 dengan FACT-G dalam struktur skala, domain sosial, dan sifat. Selain itu, perbedaan konten juga ditemukan pada skala fungsional/peran, 
pada EORTC QLQ-C30 berfokus pada aktivitas kerja dan hiburan, sedangkan FACT-G mencakup aspek kerja, koping, dan kepuasan.

Di Yunani, Georgakopoulos et al. (2013) dalam penelitiannya membandingkan EORTC QLQ-C30 dengan FACT-Lym. Pada penelitian tersebut tidak ditemukan korelasi yang lemah pada skala sosial/keluarga. Namun, hasil penelitian menunjukkan bahwa adanya korelasi yang sedang secara signifikan pada skala emosional $(\mathrm{r}=0,39)$ dan skala sosial $(\mathrm{r}=0,46)$.

Korelasi yang sedang pada skala emosional disebabkan karena adanya perbedaan konten. Skala emosional EORTC QLQ-C30 mengacu kepada keadaan mood seperti mudah marah, tegang, depresi, dan khawatir. Sementara, FACT-G menekankan pada masalah eksistensial seperti kekhawatiran tentang masa depan dan kematian (Fayers \& Machin, 2016).

Selain itu, instrumen EORTC QLQC30 membatasi pertanyaan pada aspek fungsi yang relatif objektif, sedangkan FACT-G mendorong responden untuk merefleksikan pikiran dan perasaan mereka secara keseluruhan. Perbedaan konten ini menunjukkan bahwa kedua instrumen tersebut menilai aspek yang berbeda dalam menilai kualitas hidup (Fayers \& Machin, 2016).

\section{Perbandingan Psychometric Instrumen EORTC QLQ-C30 dan FACT-G}

EORTC QLQ-C30 dan FACT-G merupakan instrumen generik yang banyak digunakan untuk mengukur kualitas hidup pasien kanker dan samasama memiliki modul tambahan. Namun, kedua instrumen tersebut memiliki perbedaan dalam hal jumlah item, struktur skala, skala respons, dan cara memberikan skoring.

Berdasarkan kriteria jumlah item, EORTC QLQ-C30 memiliki 30 item dengan bentuk kalimat pertanyaan, sementara FACT-G memiliki 27 item dengan bentuk kalimat pernyataan (Barmawi et al., 2018; Georgakopoulos et al., 2013; Sato et al., 2014; Teckle et al., 2011). Selain itu, item pada EORTC QLQC30 lebih negatif dibandingkan dengan FACT-G (Sato et al., 2014).

Item yang negatif pada instrumen dapat membuat responden kesulitan dalam menjawab pertanyaan sehingga dapat menghasilkan data yang tidak valid. Qasem \& Gul (2014) dalam penelitiannya menunjukkan bahwa arah item yang dipilih (positif atau negatif) dapat memengaruhi pada konstruksi faktorial dan validitas terkait kriteria dalam skala Likert.

Indikator skala, EORTC QLQ-C30 memiliki lima skala fungsional, tiga skala gejala, enam skala tunggal, dan satu skala kualitas hidup secara global, sedangkan pada FACT-G dan empat subskala utama, yaitu kesejahteraan fisik, sosial atau keluarga, emosional, dan fungsional (Barmawi et al., 2018; Georgakopoulos et al., 2013; Sato et al., 2014; Teckle et al., 2011). Skala kognitif, kesulitan ekonomi, dan gejala merupakan skala EORTC QLQC30 yang tidak dinilai oleh FACT-G. Selain itu, EORTC QLQ-C0 lebih menekankan pada aspek klinis, sementara FACT-G lebih berfokus pada psikososial.

Berdasarkan cara skoring, EORTC QLQ-C30 dilakukan dengan menghitung rata-rata pada seluruh komponen item (raw score), yang kemudian ditransformasikan ke 0 hingga 100 secara linear (Chen et al., 2018). Skor yang lebih tinggi pada skala fungsional menunjukkan sehat, skor tinggi pada skala status kesehatan global atau kualitas hidup menunjukkan kualitas hidup yang tinggi, sedangkan skor tinggi pada skala gejala menunjukkan adanya masalah.

Pada FACT-G, skor dihitung dengan menjumlahkan semua item (Barmawi et al., 2018). Skor yang lebih tinggi menunjukkan kualitas hidup yang baik. 


\section{Perbandingan Reliabilitas EORTC QLQ- C30 dan FACT-G}

Secara keseluruhan, EORTC QLQ-C30 dan FACT-G menunjukkan reliabilitas dan validitas yang memuaskan pada berbagai sampel jenis kanker dan negara $(\alpha \geq 0,70)$ (Ayana et al., 2016; Barmawi et al., 2018; Bener et al., 2018; Darling et al., 2006; Georgakopoulos et al., 2013; Huijer et al., 2013; Irvani et al., 2018; Magaji et al., 2015; Perwitasari et al., 2011; Sato et al., 2014; Shih et al., 2013; Silpakit et al., 2006; Teckle et al., 2011).

Di beberapa penelitian, bagaimanapun juga, ditemukan nilai $\alpha$ yang rendah pada skala kognitif, sosial serta mual dan muntah EORTC QLQ-C30 $(\alpha<0,70)$ (Ayana et al., 2016; Bener et al., 2018; Darling et al., 2006; Georgakopoulos et al., 2013; Huijer et al., 2013; Irvani et al., 2018; Magaji et al., 2015; Silpakit et al., 2006).

Sementara pada FACT-G, nilai $\alpha$ yang rendah ditemukan pada skala emosional (Barmawi et al., 2018; Georgakopoulos et al., 2013). Nilai $\alpha$ yang rendah pada EORTC QLQ-C30 disebabkan karena skala tersebut memiliki jumlah item yang sedikit. Menurut Tavakol \& Dennick (2011) mengebutkan bahwa nilai $\alpha$ yang rendah disebabkan oleh jumlah pertanyaan yang rendah, keterkaitan yang buruk antara item dan konstruk yang heterogen.

\section{Perbandingan Multitrait Scaling Analysis EORTC QLQ-C30 dan FACT-G}

Berdasarkan hasil penelitian, sebagian besar item EORTC QLQ-C30 dan FACT-G memenuhi kriteria validitas konvergen dan diskriminan. Namun, di beberapa penelitian menunjukkan bahwa item 5, 10, 15, dan 25 tidak memenuhi kriteria validitas konvergen (Huijer et al., 2013; Perwitasari et al., 2011).

Selain itu, pada EORTC QLQ-30 juga ditemukan item lima dan enam tidak memenuhi kriteria validitas diskriminan. Item tersebut memiliki korelasi yang lemah dengan skala aslinya. Sementara pada FACT-G, semua skala memenuhi kriteria validitas.

Menurut Fayers \& Machin (2016), ukuran sampel yang kecil dapat mempengaruhi korelasi dan menghasilkan nilai $\mathrm{p}$ yang tidak signifikan. Oleh karena itu, disarankan untuk menggunakan ukuran sampel yang lebih dari 100. Selain itu, kurangnya keberagaman pada sampel juga dapat membuat hasil scaling menjadi rendah (Fayers \& Machin, 2016).

\section{Known Group Comparison EORTC QLQ- C30 dan FACT-G}

Prinsip dilakukannya analisis known group comparsion untuk mengetahui dan memprediksi status kesehatan pasien kanker dengan melihat skor yang berbeda sehingga instrumen harus peka terhadap perbedaan-perbedaan tersebut. Di Ethiopia, Ayana et al. (2016) dalam penelitiannya pada EORTC QLQ-C30, menunjukkan bahwa terdapat perbedaan yang signifikan antara pasien operasi dengan radiasi di dua belas skala $(\mathrm{p}<0,05)$.

Penelitian di Cina menunjukkan ada perbedaan antara kemoterapi dengan perawatan lainnya untuk sepuluh skala $(\mathrm{p}<0,05)$ (Chen et al., 2018). Selain itu, penelitian jenis pengobatan juga dilakukan oleh Barmawi etal. (2018) yang menunjukkan ada perbedaan yang signifikan antara skor FACT-G Arab dengan jenis pengobatan. Jenis terapi yang diterima oleh pasien tentunya dapat memengaruhi kualitas hidup.

Selain itu, dalam penelitian Huijer et al. (2013) dengan EORTC QLQ-C30 menunjukkan terdapat perbedaan yang signifikan antara kualitas hidup dengan tingkat pendidikan, status pekerjaan dan usia $(\mathrm{p}<0,05)$. Sementara pada penelitian Barmawi et al. (2018) dengan FACT-G menunjukkan tidak ada perbedaan yang signifikan antara skor total FACT-G dengan usia.

Di Indonesia, hasil penelitian menunjukkan tidak ada perbedaan yang 
signifikan dalam EORTC QLQ-C30 ketika diterapkan pada diagnosis kanker yang berbeda $(P>0,05)$ (Perwitasari et al., 2011). Selain itu, hasil penelitian Teckle et al. (2011) menunjukkan bahwa EORTC QLQC30 dan FACT-G merupakan instrumen yang dapat membedakan antara pasien dengan stage awal dan akhir.

Hasil dari beberapa penelitian menunjukkan bahwa EORTC QLQ-C30 dan FACT-G sensitif dalam mengukur QoL pada jenis pengobatan dan stage kanker. Selain itu, EORTC QLQ-C30 juga sensitif pada status pekerjaan, pendidikan, dan usia, sedangkan pada FACT-G kurang dapat membedakan kelompok usia. Hal ini didasarkan pada hasil dari analisis known group comparison yang menunjukkan tidak ada perbedaan skor kualitas hidup FACT-G berdasarkan kelompok usia (Barmawi et al., 2018).

Peneliti menyadari bahwa literatur review ini memiliki kerterbatasan. Beberapa di antaranya, yaitu: (1) sulitnya mencari dan mendapatkan literatur mengenai perbandingan skor kualitas hidup pasien kanker yang menggunakan dua instrumen yaitu EORTC QLQ-C30 dan FACT-G, (2) keterbatasan dalam ketersediaan artikel dalam bentuk full-text sehingga banyak artikel yang tidak full-text diekslusikan, (3) kesulitan dalam mendapatkan artikel yang tidak dipublikasikan, (4) Adanya perbedaan analisis pada setiap studi dapat menyebabkan risiko bias.

\section{PENUTUP}

\section{KESIMPULAN}

Berdasarkan hasil pengukuran kualitas diketahui bahwa, adanya korelasi yang lemah antara EORTC QLQ-C30 dengan FACT-G pada dimensi sosial $(\mathrm{r}=0,00$ $-0,130)$, korelasi yang sedang pada dimensi fungsional $(\mathrm{r}=0,41)$ dan emosional $(\mathrm{r}=0,39)$ serta korelasi yang kuat pada dimensi kualitas hidup $(\mathrm{r}=0,54-0,76)$. EORTC QLQ-C30 dan FACT-G merupakan instrumen yang valid dan reliabel dalam mengukur kualitas hidup pasien kanker.

EORTC QLQ-C30 dan FACT-G merupakan kedua instrumen yang sensitif dalam mengukur QoL pada jenis pengobatan dan stage kanker. Namun, FACT-G kurang dapat membedakan kelompok usia dibandingkan dengan EORTC QLQ-C30.

Saran untuk penelitian selanjutnya, jika ingin menilai kualitas hidup dari berbagai aspek dan berfokus pada psikososial, peneliti merekomendasikan penggunaan FACT-G. Selain itu, FACT-G dapat digunakan pada pelayanan kesehatan dalam menilai kualitas hidup pasien kanker yang berfokus pada psikososial.

\section{DAFTAR PUSTAKA}

Ayana, B. A., Negash, S., Yusuf, L., Tigeneh, W., \& Haile, D. (2016). Reliability and Validity of Amharic Version of EORTC QLQ-C 30 Questionnaire among Gynecological Cancer Patients in Ethiopia. Plos One, 11(6), 1-10. https://doi.org/10.1371/ journal.pone.0157359

Barmawi, M. Al, Hadid, L. A. Al, Alqudah, H. N., Hadid, W. A. Al, \& Shamoun, S. A. (2018). Measuring the quality of life among head - and / or - neck cancer patients with oral mucositis using the functional assessment of cancer therapy - general in jordan. Asia-Pacific Journal of Oncology Nursing, 5(3), 320$326 . \quad$ https://doi.org/10.4103/ apjon.apjon

Bener, A., Alsulaiman, R., Doodson, L., \& Ayoubi, H. R. El. (2018). An assessment of reliability and validity of the European Organization for Research and Treatment of Cancer Quality of Life Questionnaire C30 among breast cancer patients in Qatar. Journal of Family Medicine and Primary Care, 6(4), 824-831. https://doi.org/ 10.4103/jfmpc.jfmpc

Blazeby, J. M., Kavadas, V., Vickery, C. W., 
Greenwood, R., Berrisford, R. G., \& Alderson, D. (2005). A prospective comparison of quality of life measures for patients with esophageal cancer. Quality of Life Research, 14(2), 387-393. https://doi.org/http://dx.doi.org/ 10.1007/s11136-004-0622-4

Chen, Q., Li, S., Wang, M., Liu, L., \& Chen, G. (2018). Health-related quality of life among women breast cancer patients in eastern china. BioMed Research International, 2018(1-12). https:// doi.org/10.1155/2018/1452635

Daniels, R., \& Nicoll, L. (2012). Contemporary medical-surgical nursing (2nd ed.). Delmar, Cengage Learning.

Darling, G., Eton, D. T., Sulman, J., Casson, A. G., \& Cella, D. (2006a). Validation of the functional assessment of cancer therapy esophageal cancer subscale. American Cancer Societ, 107(4), 854863. https://doi.org/10.1002/cncr.22055

Darling, G., Eton, D. T., Sulman, J., Casson, A. G., \& Cella, D. (2006b). Validation of the Functional Assessment of Cancer Therapy Esophageal Cancer Subscale. American Cancer Society, 107(4), 854-863. https://doi.org/ 10.1002/cncr.22055

Fayers, P. M., \& Machin, D. (2016). Quality of life: The assessment, analysis and reporting of patient-reported outcomes (3 rd). John Wiley \& Sons, Ltd.

Georgakopoulos, A., Kontodimopoulos, N., Chatziioannou, S., \& Niakas, D. (2013). EORTC QLQ-C30 and FACTLym for the assessment of healthrelated quality of life of newly diagnosed lymphoma patients undergoing chemotherapy. European Journal of Oncology Nursing, 17(2013). https://doi.org/10.1016/ j.ejon.2013.05.006

Huijer, H. A., Sagherian, K., \& Tamim, H. (2013). Validation of the arabic version of the EORTC quality of life questionnaire among cancer patients in lebanon. Quality of Life Research, 22, 1473-1481. https://doi.org/10.1007/ s11136-012-0261-0

Irvani, K., Jafari, P., Akhlaghi, A., \& Khademi, B. (2018). Assessing whether EORTC QLQ-30 and FACT-G measure the same constructs of quality of life in patients with total laryngectomy. Health and Quality of Life Outcomes, 16(183), 1-8.

Kementerian Kesehatan RI. (2015). Infodatin pusat data dan informasi Kementerian Kesehatan RI: Situasi penyakit kanker. Kementerian Kesehatan RI, 1-7.

Luckett, T., King, M. T., Butow, P. N., Oguchi, M., Rankin, N., Price, M. A., Hackl, N. A., \& Heading, G. (2011). Choosing between the EORTC QLQC30 and FACT-G for measuring health-related quality of life in cancer clinical. Annals of Oncology: Official Journal of the European Society for Medical Oncology, 22(10), 2179-2190. https://doi.org/http://dx.doi.org/ 10.1093/annonc/mdq721

Magaji, B., Moy, F., Roslani, A., \& Law, C. W. (2015). Psychometric validation of the malaysian chinese version of the EORTC QLQ-C30 in colorectal cancer patients. Asian Pacific Journal of Cancer Prevention, 16, 8107-8112. https:// doi.org/10.7314/

APJCP.2015.16.18.8107

Nilsson, E. (2012). Aspects of health-related quality of life: Association with psychosocial and biological factors, and use as patient-reported outcome in routine health care. Linkoping University.

Noviyani, R., Tunas, K., Indrayathi, A., \& Budiana, N. G. (2016). Uji Validitas dan Reliabilitas Kuesioner EORTC QLQ C-30 untuk Menilai Kualitas Hidup Pasien Kanker Ginekologi di RSUP Sanglah Denpasar. Farmasi Klinik Indonesia, 5(2), 106-144. https:// doi.org/10.15416/ijcp.2016.5.2.106

Perwitasari, D. A., Atthobari, J., Dwiprahasto, I., Hakimi, M., Gelderblom, H., Putter, H., Nortier, J. W. ., Guchelaar, H.-J., \& Kaptein, A. A. 
(2011). Translation and validation of EORTC QLQ-C30 into indonesian version for cancer Patients in Indonesia. Japanese Journal of Clinical Oncology, 41(4), 519-529. https:// doi.org/10.1093/jjco/hyq243

Qasem, M. A. N., \& Gul, S. B. A. (2014). Effect of items direction ( positive or negative) on the factorial construction and criterion related validity in likert scale. Journal of Humanities, 17(3), 7784.

Sato, K., Megumi, S., \& Miyashita, M. (2014). Which quality of life instruments are preferred by cancer patients in Japan? Comparison of the European Organization for Research and Treatment of Cancer Quality of Life Questionnaire-C30 and the Functional Assessment of Cancer Therapy-General. Supportive Care in Cancer, 22(12), 3135-3141. http:// dx.doi.org/10.1007/s00520-014-2287-z

Shih, C., Chen, C., Sheu, C., Lang, H., \& Hsieh, C. (2013). Validating and improving the reliability of the EORTC QLQ-C30 using a multidimensional rasch model. Value in Health, 16(5), 848-854. https:// doi.org/10.1016/j.jval.2013.05.004
Silpakit, C., Sirilerttrakul, S., Jirajarus, M., Sirisinha, T., Sirachainan, E., \& Ratanatharathorn, V. (2006). The European Organization for Research and Treatment of Cancer Quality of Life Questionnaire ( EORTC QLQC30 ): Validation study of the Thai version. Quality of Life Research, 15, 167172. https://doi.org/10.1007/s11136005-0449-7

Tavakol, M., \& Dennick, R. (2011). Making sense of Cronbach ' $\mathrm{s}$ alpha. International Journal of Medical Education, 2, 53-55. https://doi.org/ 10.5116/ijme.4dfb.8dfd

Teckle, P., Peacock, S., Mctaggart-cowan, H., Hoek, K. Van Der, Chia, S., Melosky, B., \& Gelmon, K. (2011). The ability of cancer-specific and generic preference-based instruments to discriminate across clinical and selfreported measures of cancer severities. Health and Quality of Life Outcomes, 9(106), 1-11.

Tothova, V., Bártlová, S., Dolák, F., Kaas, J., Kimmer, D., Maňhalová, J., Martinek, L., \& Olišarová, V. (2014). Quality of life in patients with chronic diseases. Neuroendocrinology Letters, 35(1), 11-18. 